\title{
PENGARUH MOTIVASI DAN LINGKUNGAN KERJA TERHADAP KINERJA PEGAWAI BADAN KEPEGAWAIAN DAN PENGEMBANGAN SUMBER DAYA MANUSIA (BKPSDM) KOTA PARIAMAN PROVINSI SUMATERA BARAT
}

\author{
Linda Fitriani, Febsri Susanti \\ Sekolah Tinggi Ilmu Ekonomi "KBP" \\ febsrisusanti@akbpstie.ac.id
}

\begin{abstract}
In this study the authors want to explain about the influence of Motivation and Work Environment on Employee Performance Personnel and Human Resource Development (BKPSDM) Pariaman City of West Sumatera Province. The purpose of this study are: 1) To explain the motivation effect on Employee Performance Personnel Board and Development Manusian Resources Pariaman City, West Sumatera Province, 2) To explain the work environment has an effect on to Personnel Employment Personnel and Manusian Resources Development of Pariaman City West Sumatera Province. This type of research is a basic study. The object of this research is BKPSDM office of Pariaman City of West Sumatera Province. This research can be concluded that Motivation and Work Environment have an effect on to Employee Performance of BKPSDM of Pariaman City of West Sumatera Province. This data is processed by using SPSS version 21 with classic assumption test and multiple regression analysis. From the test the $R$ Square value of $95.8 \%$ where this figure shows that Motivation and Work Environment Affects Employee Performance BKPSDM Pariaman. So the conclusion is Motivation and Work Environment Affects Employee Performance BKPSDM Pariaman City West Sumatra Province.
\end{abstract}

Keywords: Motivation, work environment, and employee performance

\section{PENDAHULUAN}

Dalam sebuah organisasi, organisasi selalu berusaha untuk meningkatkan atau mengembangkan kinerja pegawainya agar kepuasaan terhadap pekekerjaan di Lingkungan kerjanya berjalan dengan tujuan dan harapan dari organisasi. Saat ini perkembangan di dalam dunia birokrasi pemerintahaan dipengaruhi oleh teknologi yang didukung dengan oleh sistem manajemennya yang baik serta memadai untuk keperluan operasional maupun administrasi dalam pemerintahan. Disini organisasi pemerintah harus bisa menciptakan dan menyediakan pegawai yang cakap, ahli dalam bidangnya dan terampil, serta telah siap untuk di pakai dalam pelaksanaan tugas dan pekerjaan sebagai ASN (Aparatur Sipil Negara).

Agar kinerja pegawai selalu menghasilkan pekerjaan yang optimal serta sesuai dengan yang diharapkan oleh perusahaan, maka dibutuhkan motivasi dalam 
diri sendiri maupun dari atasan yang terus menerus, baik itu pegawai yang sudah lama bekerja maupun yang baru saja bergabung dalam perusahaan atau pada instansi pemerintah, serta kondisi lingkungan yang ada di tempat atau sekitar pekerjaan dilakukan untuk mendukung semua pekerjaan pegawai. untuk meningkatkan motivasi terhadap diri sendiri, maka jadikanlah pekerjaan tersebut sebagai suatu tanggung jawab pada diri yang benar-benar harus dipertanggungjawabkan, dan kalau dari atasan selalu melaksanakan pengawasan atau pengecekan agar pegawai tersebut serius dalam melakukan pekerjaanya. Seperti yang diketahui setiap pegawai atau staf-staf dalam melaksanakan pekerjaannya selalu diawasi oleh pimpinan sehingga pekerjaan pegawainya lebih diperhatikan dan lebih semangat lagi untuk menyelesaikan pekerjaan yang diberikan kepadanya.

Motivasi dan Lingkungan Kerja adalah salah satu faktor begitu penting yang sangat mendukung dalam kinerja atau pekerjaan pegawai, sebab motivasi itu merupakan suatu keadaan intern dari diri individu yang mengarahkan tingkah lakunya kepada sasaran tertentu, serta disinilah motivasi pimpinan sangat diperlukan atau sangat dibutuhkan pegawai untuk memberikan semangat kerja kepada pegawai untuk melakukan tugas yang sudah diberikan. Sedangkan juga mendukung dalam dunia pekerjaan. Lingkungan pada lokasi kerja yang terlihat pada kantor BKPSDM kota Pariaman terbagi dua yaitu, Lingkungan kerja fisik dan Lingkungan kerja non fisik.

Untuk meningkatkan lagi kinerja pegawai perlu adanya tenaga pegawai yang motivasi kerjanya baik serta bisa diandalkan, sebab apabila pegawai itu tidak memilih motivasi kerja maka akibatya menurunlah kinerja pegawai yang mengakibatkan organisasi pemerintah mengalami kerugian. kinerja pegawai dipengaruhi oleh beberapa, yaitu faktor yang berhubungan langsung pada pegawai serta lingkungan kerja. Lingkungan kerja yang baik akan Kinerja Pegawai mempermudah pegawai untuk menyelesaikan semua tugas-tugas yang diberikan, maka secara tidak langsung kinerja pegawai akan meningkat.

\section{LANDASAN TEORI}

Motivasi diartikan sebagai sebuah proses yang tujuannya untuk menjelaskan tentang suatu kekuatan, arahan, dan ketekunan. Terdapat tiga teori awal mengenai Motivasi: a) Teori Hierarki Kebutuhan, b) Teori X dan Teori Y, c) Teori Dua-Faktor, d) Teori Kebutuhan McClelland.

Kinerja Pegawai dipengaruhi oleh beberapa faktor yaitu diantarannya adalah penempatan yang pas dan tepat, rasa aman dimasa promosi, jumlah kompensasi yang diberikan dan latihan yang diberikan. Di samping faktor-faktor di atas masih terdapat faktor lain yang juga bisa mempengaruhi Kinerja Pegawai dalam pelaksanaan tugas yang diberikan yaitu lingkungan kerja.

Secara garis besar, jenis Lingkungan Kerja dibagi menjadi dua, yaitu: Lingkungan Fisik dan Lingkungan Non Fisik. Manfaat yang diperoleh dari lingkungan kerja yaitu sebagai salah satu hal yang bisa menciptakan semangat kerja, sehingga produktivitas dan prestasi kerja meningkat.

Kinerja dapat diartikan sebagai ukuran keberhasilan dari sebuah organisasi untuk mencapai suatu misinya. Untuk mengetahui suatu ukuran Kinerja organisasi maka bisa dilakukan penilaian kinerja. Penilaian Kinerja adalah suatu proses untuk mengevaluasi seberapa pantas dan baiknya pegawai saat melakukan suatu 
pekerjaan mereka jika dibandingkan dengan standar dan kemudian mengkomunikasikan informasi tersebut kepada semua pegawai.

Di dalam kamus Bahasa Indonesia arti kata Pegawai berasal dari kata pe dan gawai. Yang Pe merupakan sebuah awalan atau permulaan yang menunjukkan arti dari orang yang sedang mengerjakan atau mempunyai pekerjaan seperti yang disebutkan oleh kata dasar, sedangkan gawai tersebut artinya kerja.

Jadi dapat kita simpulkan bahwa Kinerja pegawai itu merupakan ketersediaan kelompok atau seseorang untuk dapat melakukan suatu pekerjaan lalu menyempurnakannya sesuai dengan tanggung jawab, sesuai dengan hasil seperti yang diharapkan oleh organisasi. pengertian kinerja atau performance disini merupakan suatu hasil kerja yang dapat dicapai oleh individu dalam suatu perusahaan atau organisasi sesuai dengan tanggung jawab dan wewenang dari masing-masing organisasi dalam upaya mencapai tujuan perusahaan secara legal serta tidak bertentangan dengan etika atau moral serta melanggar hukum. terdapat beberapa metode di dalam penilaian kinerja yang terdiri dari beberapa hal yaitu:

1. Metode Skala Penilaian Grafik

2. Metode Skala Penilaian Perilaku,

3. Metode Manajemen Berdasarkan Sasaran

Beberapa aspek dalam kinerja yang meliputi antara lain:

1. Kualitas pekerjaan

2. Kuantitas pekerjaan

3. Pengenalan pekerjaan dan Pemahaman pekerjaan

4. Kemampuan dalam memecahkan persoalan

5. Kemampuan untuk melakukan pekerjaan sendiri

Substansi instrumen pengukuran kinerja terdiri dari beberapa aspek yang berpengaruh pada kualitas pelaksanaan tugas dan bisa diukur, yaitu meliputi antara lain:

1. Achievement (Prestasi Kerja)

2. Skill (Keahlian)

3. Attitude (Perilaku)

4. Leadership (Kepemimpinan)

Agar dapat memperoleh hasil kinerja yang memuaskan, maka prestasi kerja yang tepat berfokus pada:

1. Solusi waktu jangka panjang

2. Pemberian penghargaan terhadap usaha dan kemampuan dalam melaksanakan tugas dan pekerjaan yang diberikan

3. Memberikan pujian dan penghargaan pada pegawai yang berprestasi

4. Memberikan pujian dan penghargaan terhadap komitmen dan loyalitas

5. Memberikan pujian dan penghargaan pada pegawai yang kreativitas

6. Memberikan pujian penghargaan terhadap perkembangan dan pertumbuhan kinerja karyawan

7. Memberikan pujian dan penghargaan pada kinerja tim dan kerja sama

8. Tingkat perolehan terhadap penghargaan.

Sedangkan manfaat penilaian kinerja SDM, disini menurut Handoko (1992) yaitu:

1. Perbaikan kinerja

2. Penyesuaian-penyesuaian kompensasi

3. Keputusan-keputusan penempatan 
4. Pengembangan dan Perencanaan karir

5. Pengembangan dan Kebutuhan-kebutuhan latihan

6. Penyimpangan dari proses susunan pegawai

7. Ketidak akuratan dari suatu informasi

8. Kesalahan-kesalahan dari bentuk desain pekerjaan.

\section{METODE PENELITIAN}

\section{Jenis Penelitian}

Dalam suatu kegiatan penelitian, pendekatan dengan membangun teori secara ilmiah ditunjukan untuk mendapatkan bentuk kerangka konseptual yang teroritik dan terarah secara sistematik. Adapun alur hubungan tersebut antara teori dengan penelitian merupakan satu kesatuan untuk mencari kebenaran. Dalam penelitian ini, peneliti melakukan penelitian pada BKPSDM Kota Pariaman.

\section{Lokasi / Objek Penelitian}

Lokasi penelitian merupakan suatu tempat dalam memperoleh atau mendapatkan data-data yang diperlukan sehubungan dengan penulisan skripsi ini. Lokasi penelitian dilakukan di BKPSDM Kota Pariaman Provinsi Sumatera Barat yang beralamatkan di Jalan Imam Bonjol No. 44 Kota Pariaman. Lokasi perusahaan merupakan salah satu kebutuhan fisik yang mutlak diperlukan. Objek kajian didalam penelitian ini ialah bagaimana didalam menentukan harga pokok penjualan berdasarkan metode penelitian pada PT.Sukses Makmur Pratama.

\section{Populasi dan Sampel}

Populasi merupakan wilayah generalisasi yang terdiri dari sabjek atau objek yang mempunyai karakteristik dan kuantitas tertentu yang ditetapkan oleh peneliti untuk dipelajari dan kemudian ditarik kesimpulannya. Yang menjadi populasi disini adalah semua pegawai yang bekerja di kantor Balaikota pada bagian Badan Kepegawaian dan Pengembangan Sumber Daya Manusia atau yg disingkat dengan BKPSDM kota Pariaman Provinsi Sumatera Barat.

Sampel adalah Sebagian dari populasi yang diteliti. Yang menjadi sampel disini yaitu seluruh pegawai yang bekerja di kantor Balaikota pada bagian BKPSDM kota Pariaman Provinsi Sumatera Barat, yang memiliki pusat kantor di Balaikota Pariaman dimana disitu kuesioner peneliti sebarkan.

\section{Jenis dan Sumber Data}

Jenis data dalam penelitian ini adalah data kualitatif yaitu mengelola secara deskriptif data yang diperoleh dari perusahaan. Sumber data yang dikumpulkan dalam penelitian ini adalah data primer. Data primer diperoleh secara lansung dari objek yang diteliti. Sumber Data yaitu Data Primer, Data Primer yaitu data yang dikumpulkan oleh si peneliti itu sendiri yang datanya merupakan data yang belum pernah ada dikumpulkan sebelumnya oleh peneliti lain, baik dengan cara tertentu ataupun pada periode waktu yang tertentu.

\section{Teknik Pengumpulan Data}

Metode atau teknik pengumpulah data yang digunakan didalam penelitian ini dengan 3 cara :

1. Observasi

Observasi suatu teknik dalam pengumpulan data yang mempunyai ciri-ciri yang spesifik kalau dibandingkan dengan teknik-teknik lain, seperti kuesioner dan wawancara. 
2. Kuesioner

Kuesioner merupakan teknik pengambilan data yang biasanya dilakukandengan cara memberikan beberapa pernyataan tertulis atau pertanyaan kepada responden untuk kemudian dijawab (Sugiono,2015).

3. Interview

Menurut (Esterberg dalam Sugiyono 2013) Interview adalah pertemuan dua orang yang melakukan tanya jawab, bertukar ide dan bertukar informasi, sehingga bisa dikontruksikan maknanya dalam suatu topik tertentu.

\section{Teknik Analisis Data}

\section{a) Uji Instrumen Penelitian}

1.Uji Validitas.

Yang di uji dalam uji validitas ini adalah pertanyaan atau pernyataan (item atau butir-butir saja) yang nama indikatornya adalah corrected item total correlation (citc).

2. Uji Reliabilitas

Berfungsi mengolah data untuk mengukur suatu kuesioner yang merupakan suatu indikator dari variabel atau konstruk. kuesioner bisa dikatakan reliabel atau handal jika jawaban dari individu terhadap pernyataan konsisten atau stabil dari waktu ke waktu.

\section{b) Uji Asumsi Klasik}

\section{Uji Normalitas}

Kesimpulan uji asumsi Klasik yaitu sebuah Uji Normalitas dilakukan tujuannya untuk menilai sebaran data pada sebuah kelompok data apakah sebaran data tersebut berdistribusi normal atau tidak.

\section{Uji Multikolinieritas}

Multikolinieritas artinya yaitu adanya hubungan yang begitu kuat antara beberapa variabel atau semua variabel bebas pada model regresi. Jika terdapat Multikolinieritas maka hasil koefisien regresi menjadi tidak tentu, tingkat kesalahannya menjadi sangat besar dan biasanya ditandai dengan nilai koefisien determinasi yang sangat besar, tetapi pada pengujian person koefisien regresi, tidak ada atau kalaupun ada sangat sedikit sekali koefisien regresi yang signifikan.

\section{Uji Heteroskedastisitas}

Heteroskedastisitas adalah suatu indikasi varian antar residual yang tidak homogen yang mengakibatkan nilai taksiran yang diperoleh tidak lagi efisien.

\section{c) Uji Hipotesis}

Menurut (Sugiyono, 2013), hipotesis merupakan dugaan sementara terhadap rumusan masalah penelitian, dimana rumusan masalah penelitian tersebut telah dinyatakan dalam bentuk kalimat pertanyaan. Berikut adalah bagian dari uji hipotesis:

\section{Uji T Statistik}

Uji t digunakan untuk menguji hipotesis secara parsial yang gunanya untuk menunjukkan pengaruh dari tiap-tiap variabel independen secara individu terhadap variabel dependen. 


\section{Uji Realibilitas}

Uji Realibilitas merupakan suatu instrumen yang cukup dapat dipercaya untuk menguji sebagai alat pengumpul data sebab instrument tersebut sudah baik menurut (Suharsimi Arikunto, 2006).

\section{HASIL PENELITIAN}

\section{Sejarah BKPSDM Kota Pariaman}

Badan Kepegawai Daerah Kota Pariaman di bentuk pada tahun 2007 dalam suatu Peraturan Daerah No. 04 Tahun 2007 tentang Keputusan Walikota Pariaman No. 04 Tahun 2007 tentang Susunan Organisasi dan Tata kerja Badan Kepegawai Daerah Kota Pariaman. Badan Kepegawai Daerah dikepalai oleh seorang Kepala dan memiliki satu Sekretaris dan tiga Kepala Bidang serta enam Kepala Sub Bidang, tiga Kepala Sub Bagian serta beberapa orang Staf.

2. Perolehan Data

Penelitian ini dilakukan pada kantor Badan Kepegawaian dan Pengembangan Sumber Daya Manusia atau yang disingkat dengan (BKPSDM) kota Pariaman Provinsi Sumatera Barat yang berada di Kota Pariaman dan disinilah data peneliti peroleh.

3. Hasil Uji Kualitas Data

\section{a.Uji validitas Data}

\section{1) Uji Validitas Motivasi (X1)}

Tabel 1

Hasil Uji validitas Motivasi

\begin{tabular}{|c|c|c|c|}
\hline No Butir Pertanyaan & R hitung & R table & Keterangan \\
\hline 1 & 0.693 & 0.361 & Valid \\
\hline 2 & 0.670 & 0.361 & Valid \\
\hline 3 & 0.693 & 0.361 & Valid \\
\hline 4 & 0.670 & 0.361 & Valid \\
\hline 5 & 0.693 & 0.361 & Valid \\
\hline 6 & 0.617 & 0.361 & Valid \\
\hline 7 & 0.670 & 0.361 & Valid \\
\hline 8 & 0.617 & 0.361 & Valid \\
\hline
\end{tabular}

Sumber :Diolah spss versi 21

Dari table diatas dapat disimpulkan bahwa dari 8 item pertanyaan variabel Berdasarkan tabel dapat diketahui dari bahwa pertanyaan kuesioner Motivasi memiliki instrumen yang valid karena dari hasil $r$ hitung lebih besar dari $r$ tabel. 
2) Uji Validitas Lingkungan Kerja (X2)

Tabel 2

Hasil Uji validitas Lingkungan Kerja (X2)

\begin{tabular}{|c|c|c|c|}
\hline No Butir Pertanyaan & R hitung & R table & Keterangan \\
\hline 1 & 0.748 & 0.361 & Valid \\
\hline 2 & 0.748 & 0.361 & Valid \\
\hline 3 & 0.433 & 0.361 & Valid \\
\hline 4 & 0.647 & 0.361 & Valid \\
\hline 5 & 0.499 & 0.361 & Valid \\
\hline 6 & 0.647 & 0.361 & Valid \\
\hline 7 & 0.616 & 0.361 & Valid \\
\hline 8 & 0.748 & 0.361 & Valid \\
\hline
\end{tabular}

Sumber :Diolah spss versi 21

Dari table diatas dapat disimpulkan bahwa dari 8 item pertanyaan variabel menunjukan bahwa variabel Lingkungan Kerja mempunyai kriterian untuk semua pertanyaan kuesioner Lingkungan Kerja bahwa $r$ tabel kecil dari $\mathrm{r}$ hitung semuanya diatas 0,3. Maka dari itu dapat disimpulkan bahwa pertanyaan dari Lingkungan Kerja dapat dikatakan valid.

3) Uji Validitas Kinerja Pegawai (Y)

Tabel 3

Hasil Uji validitas Kinerja Pegawai (Y)

\begin{tabular}{|c|c|c|c|}
\hline No Butir Pertanyaan & R hitung & R table & Keterangan \\
\hline 1 & 0.445 & 0.361 & Valid \\
\hline 2 & 0.841 & 0.361 & Valid \\
\hline 3 & 0.473 & 0.361 & Valid \\
\hline 4 & 0.841 & 0.361 & Valid \\
\hline 5 & 0.501 & 0.361 & Valid \\
\hline 6 & 0.841 & 0.361 & Valid \\
\hline 7 & 0.445 & 0.361 & Valid \\
\hline 8 & 0.506 & 0.361 & Valid \\
\hline 9 & 0.841 & 0.361 & Valid \\
\hline 10 & 0.841 & 0.361 & Valid \\
\hline
\end{tabular}

Sumber :Diolah spss versi 21

Dari table diatas dapat disimpulkan bahwa dari 10 item pertanyaan variabel Kinerja Pegawai dikatakan valid karena dari pertanyaan tersebut $r$ hitung > $r$ tabel.

\section{b. Uji Reliabilitas}

Tabel 4

Hasil Uji Reliabilitas

\begin{tabular}{|c|l|c|c|l|}
\hline No & Variabel & Batas Nilai & Cronbach's Alpha( $\boldsymbol{\alpha})$ & Ket \\
\hline 1 & Motivasi (X1) & 0,6 & 0,890 & Realibel \\
\hline 2 & Lingkungan Kerja (X2) & 0,6 & 0,872 & Realibel \\
\hline 3 & Kinerja Pegawai (Y) & 0,6 & 0,904 & Realibel \\
\hline
\end{tabular}

Sumber : Data diolah SPSS 21

Berdasarkan tabel di atas diketahui bahwa hasil uji reliabilitas menentukan koefisien Cronbach's Alpha( $\alpha)$ secara keseluruhan sudah 
reliabilitas dengan nilai Cronbach's Alpha( $\alpha)$ sebesar 0,6 yang menunjukkan bahwa semua variabel tersebut dapat dipakai sebagai penelitian.

\section{c. Uji Asumsi Klasik}

1. Uji Normalitas

\section{Gambar 1}

Hasil Normalitas berdasarkan Grafik Histogram

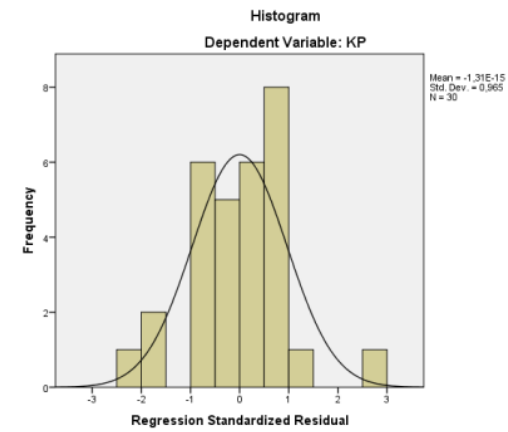

\section{Sumber : Data diolah SPSS 21}

Dari gambar dapat diketahui bahwa data yang di ujikan normal. Karena grafik mengikuti alur histrogram yaitu naik turun histogram dan penyebarannya berada di alur histogram.

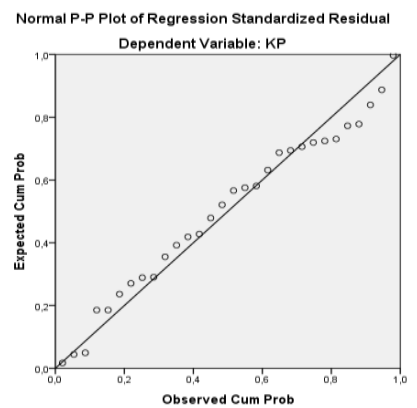

Sumber : Data diolah SPSS 21

\section{Hasil Uji Normalitas Mengunakan Grafik Plot}

Berdasarkan gambar bisa diketahui bahwa penyebaran titik lingkaran mendekati garis titik potong jadi dapat dikatakan bahwa data berdistribusi normal:

Tabel 5

One-Sample Kolmogorov-Smirnov Test

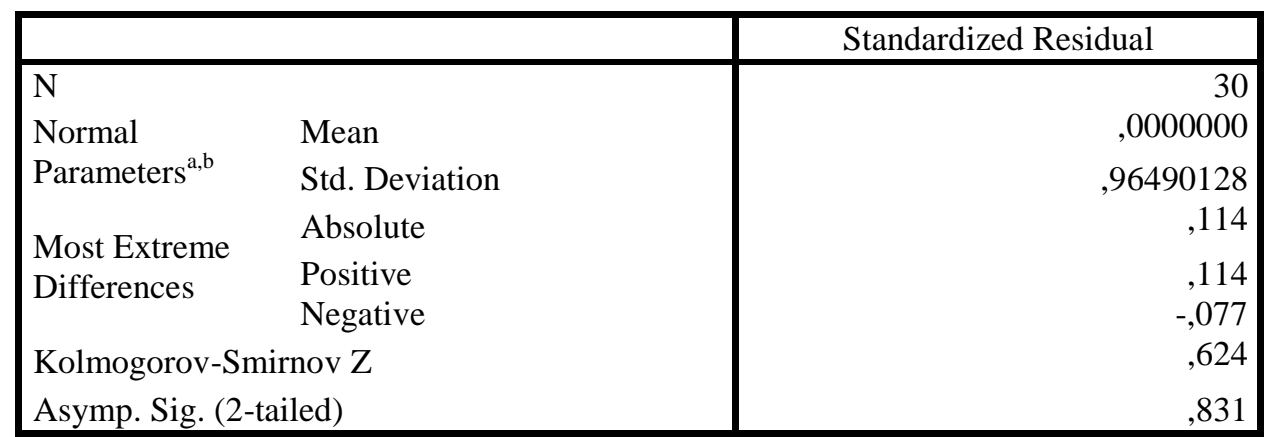

a. Test distribution is Normal.

b. Calculated from data.

Sumber : Data diolah SPSS 21 
Berdasarkan Tabel uji normal besarnya nilai test satistic kolmogrov-smirnov singnifikan adalah 0,831 dan .Nilai tersebut lebih besar dari 0,05 yang dapat disimpulkan bahwa residual tersebut normal.

\section{d. Uji Heterokedastisitas}

Uji heteroskedastisitas dengan GI

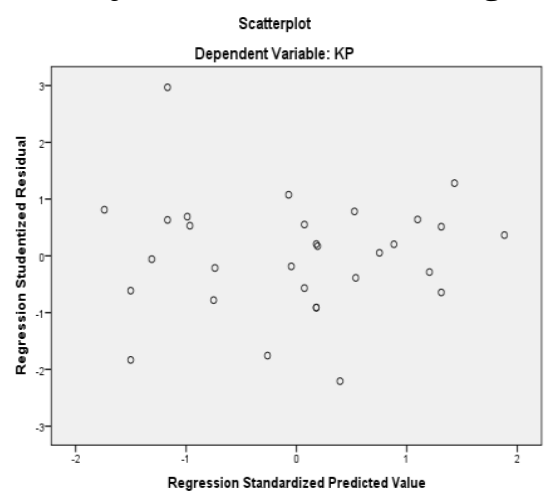

Sumber : Data diolah SPSS 21

Dari gambar tidak terjadi heteroskedastisitas karena titik-titik menyebar ke atas dan di bawah angka 0 pada sumbu Y .

Dari gambar Apabila titik-titik menyebar dan tidak membentuk pola maka dapat dikatakan tidak terjadi heterokedastisitas. Dan kalau dilihat pada gambar di atas bahwa tidak terjadi heteroskedastisitas karena titik-titik menyebar ke atas dan di bawah atau tidak membentuk suatu pola.

\section{e. Uji Multikornelitas}

\section{Hasil Uji Multikornelitas} Coefficients $^{\mathrm{a}}$

\begin{tabular}{|c|c|c|c|c|c|c|c|c|}
\hline \multirow[t]{2}{*}{ Model } & \multicolumn{2}{|c|}{$\begin{array}{c}\text { Unstandardized } \\
\text { Coefficients }\end{array}$} & $\begin{array}{c}\text { Standardized } \\
\text { Coefficients }\end{array}$ & \multirow[t]{2}{*}{$\mathrm{t}$} & \multirow[t]{2}{*}{ Sig. } & \multicolumn{3}{|c|}{$\begin{array}{c}\text { Collinearity } \\
\text { Statistics }\end{array}$} \\
\hline & B & Std. Error & Beta & & & Tole & ance & VIF \\
\hline (Constant) & & $-2,482$ & 2,522 & &,- 984 & ,334 & & \\
\hline MO & & 682 & ,145 & 542 & 4,696 & ,000 & 239 & 4,187 \\
\hline LK & & ,614 & ,159 & ,445 & 3,855 & ,001 & 239 & 4,187 \\
\hline
\end{tabular}

Sumber : Data diolah SPSS 21

Berdasarkan pada tabel diatas dapat dilihat bahwa nilai toleransi 0,239 dan nilai VIF 4.187 Dimana nilai VIF kecil dari 10 dan nilai Tolerance lebih besar dari 0,1

Maka dapat disimpulkan bahwa tidak terjadi masalah multikononieritas antara independen dalam model regresi.

\section{F. Uji Regresi Berganda.}

\section{Uji Regresi Berganda}

Coefficients $^{\mathrm{a}}$

\begin{tabular}{|c|c|c|c|c|c|c|c|}
\hline \multirow[t]{2}{*}{ Model } & \multicolumn{2}{|c|}{$\begin{array}{l}\text { Unstandardized } \\
\text { Coefficients }\end{array}$} & $\begin{array}{l}\text { Standardized } \\
\text { Coefficients }\end{array}$ & \multirow[t]{2}{*}{$\mathrm{t}$} & \multirow[t]{2}{*}{ Sig. } & \multicolumn{2}{|c|}{$\begin{array}{l}\text { Collinearity } \\
\text { Statistics }\end{array}$} \\
\hline & $\mathrm{B}$ & Std. Error & Beta & & & Tolerance & VIF \\
\hline (Constant) & $-2,482$ & 2,522 & &,- 984 & ,334 & & \\
\hline $1 \mathrm{MO}$ & ,682 & , 145 & ,542 & 4,696 &, 000 & ,239 & 4,187 \\
\hline LK & ,614 & , 159 & , 445 & 3,855 & ,001 & ,239 & 4,187 \\
\hline
\end{tabular}


Model Analisis Berganda

Dimana :

$$
\begin{aligned}
& Y=a+b 1 . X I+b 2 . X 2+e \\
& Y=-0,2482+0,682 X 1+0,614 X 2
\end{aligned}
$$

$\mathrm{Y}=$ Kinerja Pegawai

$\mathrm{A}=$ Konstanta

$\mathrm{B}=$ Koefisien Variabel

$\mathrm{X} 1$ = Motivasi

$\mathrm{X} 2$ = Lingkungan Kerja

$\mathrm{E}=$ Standar Error

A. Uji Hipotesis

1 Uji Signifikansi Simultan(Uji Statistik F)

Hasil Uji Statistik F

\begin{tabular}{|c|c|c|c|c|c|c|}
\hline \multicolumn{2}{|c|}{ Model } & $\begin{array}{l}\text { Sum of } \\
\text { Squares }\end{array}$ & Df & Mean Square & $\mathrm{F}$ & Sig. \\
\hline \multirow{3}{*}{1} & Regression & 491,459 & 2 & 245,730 & 305,177 &, $000^{\mathrm{b}}$ \\
\hline & Residual & 21,741 & 27 & ,805 & & \\
\hline & Total & 513,200 & 29 & & & \\
\hline
\end{tabular}

ANOVA $^{\text {a }}$

a. Dependent Variable: KP

b. Predictors: (Constant), LK, MO

Sumber : Data diolah SPSS 21

Dari tabel 4.14 dapat dilihat bahwa pengujian nilai signifikan hipotesis secara simultan adalah 0,000 dapat diartikan bahwa nilai nilai signifikan lebih kecil 0,05 maka dapat dikatakan berpengaruh dan signifikan secara bersamaan antar variabel Motivasi (X1), Lingkungan Kerja (X2) terhadap Kinerja Pegawai (Y).

\section{Uji Signifikansi Parsial (Uji t)}

Ho : Ditolak apabila T hitung $<\mathrm{T}$ tabel dan signifikan $>0,05$

Ha : Diterima apabila $\mathrm{T}$ hitung lebih besar dari $\mathrm{T}$ tabel dan signifikan $>0,05$.

Hasil Uji t

Coefficients $^{\mathrm{a}}$

\begin{tabular}{|l|r|r|r|r|r|}
\hline Model & \multicolumn{2}{|c|}{$\begin{array}{c}\text { Unstandardized } \\
\text { Coefficients }\end{array}$} & \multicolumn{2}{c|}{$\begin{array}{c}\text { Standardized } \\
\text { Coefficients }\end{array}$} & \multirow{2}{*}{ Sig. } \\
\cline { 2 - 4 } & \multicolumn{1}{|c|}{ B } & Std. Erraor & Beta & & \\
\hline (Constant) & $-2,482$ & 2,522 & &,- 984 &, 334 \\
MO &, 682 &, 145 &, 542 & 4,696 &, 000 \\
LK &, 614 &, 159 &, 445 & 3,855 &, 001 \\
\hline
\end{tabular}

a. Dependent Variable: KP

Sumber : Data diolah SPSS 21

Berdasarkan tabel dapat diketahui bahwa untuk variabel Pengaruh Motivasi (X1) nilai t hitung adalah sebesar 4,696 dan dengan nilai signifikan 0,00 yang artinya kecil dari 0,05. Maka H1 Diterima karena dapat berpengaruh signifikan terhadap Kinerja Pegawai (Y).

Dari tabel di atas dapat diketahui bahwa untuk variabel Lingkungan Kerja (X2) t hitungnya adalah sebesar 3,855 dengan nilai signifikannya sebesar 0,00 
dimana kecil dari 0,05. Maka H1 Diterima kareana dapat berpengaruh signifikan terhadap Kinerja Pegawai (Y).

Koefisien Determinasi (Adjusted $\mathbf{R}^{2}$ )

Uji R

Model Summary ${ }^{\mathrm{b}}$

\begin{tabular}{|l|r|r|r|r|}
\hline Model & R & \multicolumn{1}{|c|}{ R Square } & \multicolumn{1}{|c|}{$\begin{array}{c}\text { Adjusted R } \\
\text { Square }\end{array}$} & $\begin{array}{c}\text { Std. Error of the } \\
\text { Estimate }\end{array}$ \\
\hline 1 &, $956^{\mathrm{a}}$ &, 914 &, 908 & 1,820 \\
\hline
\end{tabular}

a. Predictors: (Constant), LK, MO

b. Dependent Variable: KP

\section{Sumber : Data diolah SPSS 21}

Berdasarkan tabel 4.16 diatas dapat diketahui nilai Adjusted R squarenya adalah sebesar 0,914 atau setara dengan 91,4\%. Maka dari tabel di atas dapat disimpulkan bahwa 91,4\% mempengaruhi variabel dari Motivasi dan Lingkungan KerjaTerhadap Kinerja Pegawai . Sedangkan sisanya sebesar 8,6\% di pengaruhi oleh variabel-variabel lain yang tidak diteliti dalam penelitian ini.

\section{PEMBAHASAN}

\section{Pengaruh Motivasi dan Lingkungan Terhadap Kinerja Pegawai}

Pada penelitian ini menunjukkan bahwa penilaian responden terhadap variabel-variabel penelitian ini sudah baik. Yang dilihat dari tanggapan setuju yang tinggi dari responden. Berikut ini adalah penjelasan masing-masing variabel.

Dalam pengujian secara parsial (uji T), menunjukkan bahwa, variabel Pengaruh Motivasi berpengaruh signifikan terhadap Kinerja Pegawai terlihat dari nilai signifikannya yaitu $0,00<0,05$. Bahwa penelitian (Ni made suari, 2013) menunjukkan Pengaruh Motivasi dan Lingkungan Kerja Terhadap Kinerja Pegawai.

\section{Lingkungan Kerja Terhadap Kinerja Pegawai}

Dalam pengujian hipotesis uji $\mathrm{T}$ bahwa variabel Lingkungan Kerja berpengaruh positif dan signifikan terhadap Kinerja Pegawai terlihat dari nilai signifikannya adalah $0,00<0,05$. Penelitian (Ni made suari, 2013) bahwa Lingkungan Kerja berpengaruh positif dan signifikan terhadap Kinerja Pegawai.

Sedangkan terlihat pada uji $\mathrm{F}$ bahwa nilai signifikan Variabel X1 dan X2 sebesar $0,00<0,05$. Jadi dapat disimpulkan bahwa Motivasi (X1) dan Lingkungan Kerja (X2) berpengaruh positif dan signifikan terhadap Kinerja Pegawai.

\section{KESIMPULAN}

Berdasarkan penelitian yang dilakukan dapat disimpulkan bahwa objek penelitian pada Instansi Pemerintahan Kota Pariaman yaitu BKPSDM Kota Pariaman. Data yang digunakan dalam penelitian adalah penyebaran kuesioner kepada seluruh pegawai yang bekerja di kantor BKPSDM tersebut. Data di olah menggunakan analisis linear berganda dan uji yang digunakan adalah uji normalitas, uji heterokedastisitas,uji multikolinearitas,dan pengujian hipotesis menggunakan uji $\mathrm{F}$ dan uji $\mathrm{T}$.

Berdasarkan hasil pengujian hipotesis 1 dalam uji $\mathrm{T}$ tersebut menyatakan bahwa Motivasi berpengaruh positif dan signifikan terhadap Kinerja Pegawai. 
Motivasi t hitungnya sebesar $4.242>\mathrm{t}$ tabel yaitu 2052 dengan nilai signifikan $0,000<0,05$. dan pada hipotesis 2 juga berpengaruh positif dan signifikan antara Lingkungan Kerja terhadap Kinerja Pegawai. Lingkungan Kerja t hitung $>t$ tabel yaitu 2,052 dengan nilai signifikan $0,00<0,05$.

Berdasarkan uji $\mathrm{F}$ bahwa Pengaruh Motivasi dan Lingkungan Kerja berpengaruh positif dan signifikan terhadap Kinerja Pegawai. Pengujian nilai signifikan hipotesis secara simultan adalah sebesar 0,00 dengan nilai signifikan < 0,05. Berpengaruh dan signifikan secara bersamaan antara variabel Motivasi dan Lingkungan Kerja Terhadap Kinerja Pegawai. Dapat diketahui nilai R squarenya adalah sebesar 0,958. Dapat menunjukkan bahwa Motivasi dan Lingkungan Kerja Terhadap Kinerja Pegawai sebesar 95,8\%. Sedangkan sisanya sebesar 4,2\% di pengaruhi oleh variabel-variabel lain yang tidak diteliti dalam penelitian ini

\section{DAFTAR PUSTAKA}

Aldi, Y., \& Susanti, F. (2019). Pengaruh Stress Kerja Dan Motivasi Kerja Terhadap Prestasi Kerja Karyawan Pada PT. Frisian Flag Indonesia Wilayah Padang. https://doi.org/10.31227/osf.io/et4rn

Aziz, N. (2019). Pengaruh Lingkungan Kerja Terhadap Kinerja Yang Dimediasi Oleh Motivasi Kerja Karyawan Rocky Plaza Hotel Padang. https://doi.org/10.17605/OSF.IO/E4C59

Junaidi, R., \& Susanti, F. (2019). Pengaruh Gaya Kepemimpinan Dan Budaya Organisasi Terhadap Kinerja Pegawai Pada UPTD Baltekkomdik Dinas Pendidikan Provinsi Sumatera Barat. https://doi.org/10.31227/osf.io/bzq75

Ghozali, (20016). Aplikasi Analisis Multivariate Dengan Program IBM Versi 21. Serang Undip

Mayliza, R. (2019). Pengaruh Kompensasi Finansial, Lingkungan Kerja Dan Motivasi Kerja Terhadap Kinerja Pegawai Pada Kantor PDAM Kota Payakumbuh. https://doi.org/10.17605/OSF.IO/DZXAF

Mayliza, R. (2019). Kontribusi Sistem Penghargaan Dan Lingkungan Kerja Terhadap Efektifitas Kerja Pegawai Pada Kantor Dinas Pendidikan Kota Padang. https://doi.org/10.17605/OSF.IO/VWZH3

Munparidi. 2012. Pengaruh Kepemimpinan, Motivasi, Pelatihan dan Lingkungan KerjaTerhadap Kinerja Karyawan pada Perusahaan Daerah Air Minum tirta Musi Kota Palembang. Jurnal Orasi Bisnis Edisi ke-VII, Mei 2012. Diambil dari:https://scholar.google.co.id.

Murti Harry, Agustini Verinika, dan Srimulyani. 2013. Pengaruh Motivasi Terhadap KinerjaPegawai Dengan Variabel PDAM Kota Madiun. Jurnal Riset Manajemen dan Akuntansi Vol. 1 No. 1, Februari 2013. Diambil:https://scholar.google.co.id. 
Ridho, M., \& Susanti, F. (2019). Pengaruh Stres Kerja Dan Motivasi Kerja Terhadap Kepuasan Kerja Pada Karyawan Bank Mandiri Syariah Cabang Padang. https://doi.org/10.31227/osf.io/pa2cg

Robbins, Stephen P. dan Judge, Timothy A. 2015. Perilaku Organisasi. Salemba Empat:Jakarta.

Yudistira, D. S., \& Susanti, F. (2019). Pengaruh Motivasi Kerja Dan Budaya Kerja Terhadap Kinerja Karyawan Dinas Pemberdayaan Masyarakat Dan Desa, Pengendalian Penduduk Dan Keluarga Berencana Kabupaten Pesisir Selatan. https://doi.org/10.31227/osf.io/jk54m 